\title{
Quality of Electricity Supply as a Service
}

\author{
Ervin SERŠEN ${ }^{1}$, Jože VORŠIČ ${ }^{2}$ \\ ${ }^{1}$ The Energy Agency of the Republic of Slovenia \\ Strossmayerjeva ulica 30, 2000 Maribor, Slovenija \\ Phone: +386 (0)2 23403 00,Fax: +386 (0)2 23403 20, e-mail: ervin.sersen@agen-rs.si \\ ${ }^{2}$ University of Maribor, Faculty of electrical engineering and computer science, \\ Power Engineering Laboratory \\ Smetanova ulica 17, 2000 Maribor, Slovenija \\ Phone: +386 (0)2 22070 50,Fax: +386 (0)2 25254 81, e-mail: vorsic@uni-mb.si
}

\begin{abstract}
Electricity supply has nowadays become a part of every day life and is a service expected by electricity consumers. Their expectations rely on the availability of electricity whenever needed and on a safe and satisfactory operation of all connected electrical devices.

The expenses of electricity quality are in the time of open market very important to the consumers and especially to the industry. They in fact signify an additional value which can be ensured to the consumers by the suppliers in order to increase their productivity and reliability of the production process.

In order to carry out economic regulation of network charge, the Energy Agency of the Republic of Slovenia (Slovenian regulator) monitors the quality of electricity supply, which is divided into: reliability (continuity) of supply, voltage quality and commercial quality. The Agency monitors the parameters of quality electricity supply with the intention of permanently increasing and maintaining its level, respectively.

At the other side on have to know where the disturbances are coming. In the past, research of transiting disturbance from one part of energy system to another was carried out by means of different instruments and methods, from computer to experimental. Transient system analyzers provided good matches with field measurements, still their usage in the increasingly extensive systems has become useless (unfeasible or inaccurate). "Live" research is nowadays practically unfeasible on a mid-voltage or high voltage level.

The development of big digital computers has brought about new possibilities in this area. Thirty years ago, a wide number of methods came to light along with their specificity for digital solutions of transient phenomena in an electricity system. Current PCs are capable enough and programs can be obtained in a user-friendly form.
\end{abstract}

\section{Key words}

Electricity supply, network charge, reliability of supply, voltage quality, commercial quality

\section{Introduction}

Quality of electricity supply in every day life means a minimal number of interruptions and their duration kept to a minimal period of time. A safe and satisfactory device operation is ensured when the devices are connected to voltage which is within the prescribed tolerances for voltage and frequency. Even short-term interruptions on the basic form of voltage can cause irregular operation of devices.

The Council of European Energy Regulators (CEER) has divided quality of electricity supply to:

- commercial quality, dealing with service between the supplier or system operator and the consumer,

- continuity (reliability) of supply, dealing with the number and duration of interruptions spotted with consumers,

- quality of voltage which contains the technical characteristics of voltage measured in the receivingtransmitting point of the consumer.

Agency's main task is to prepare and issue the methodology for the calculation of network charge and methodology for setting out the criteria for defining eligible costs. while taking into consideration the mechanisms of promotion, manifested in the field of investment, ascertaining technical losses of the system and maintenance. A decrease of costs in a company can be most easily reached by means of decreasing costs in the field of maintenance and investment, which can also lead to a lower quality level.

In August 2005, the Energy Agency of the Republic of Slovenia (hereafter the agency) prepared a consultation document explaining which quality parameters it will control and also published the manner of price connection for the usage of systems. 


\section{Legal bases for quality of electricity supply}

The Energy Act (Official Gazette of the Republic of Slovenia No.: 27/07; EZ-UPB2) states reliable electricity supply as one of the principles of energy policy. In Article 9 it is stated that energy policy ensures quality and reliable energy supply.

Article 69 states that the provider of economic public services is required to be organized in a manner to be able to receive information from the consumers about interruptions in cases of electricity supply and, if required by the consumer, to eliminate interruptions disabling electricity consumption as soon as possible or within the deadline determined by Decree on general conditions for the supply and consumption of electricity.

Article 18 states that a system operator is required to prepare a plan of the development of the distribution system every two years for the next ten years while considering the data on system occupation and their analysis, respectively. System development must take into consideration the principles of supply quality, supply reliability and economy of construction, maintenance and operation.

Decree on the method for the implementation of public service obligation relating to the electricity distribution system operator, and public service obligation relating to the electricity supply to tariff costumers defines quality demands as stated in CEER. Distribution system operator must monitor and establish quality of electricity supply.

The Decree on the method for implementing public service obligation relating to the activity of transmission system operator states that the transmission system operator (TSO) is obliged to ensure voltage quality monitoring, a base for the preparation of the annual report which includes time distribution duration of a number of system intervention due to planned and unplanned work.

For high-voltage systems it is demanded from the system operator to ensure on the transmission system such electricity quality that the operator on the mid-voltage level can ensure voltage quality in accordance with Article 28 of the Decree on the method for the implementation of public service obligation relating to the electricity distribution system operator, and public service obligation relating to the electricity supply to tariff costumers.

\section{Quality parameters and methodology of network charge setting}

As mentioned earlier, quality is divided into commercial quality, supply reliability and voltage quality. All three types of quality are prescribed in the above mentioned implementing regulations.

System operators can conclude contracts with consumers on electricity quality, in which they establish a nonstandard electricity quality. The contract can define special terms of connection, stand-by supply and the manner of monitoring electricity quality.

Act determining the methodology for the calculation of network charge and methodology for setting the network charge, and the criteria for determining eligible costs for electricity networks, issued by the agency, demands parameter monitoring in the manner which has been in operation so far. In the regulatory period of 2006-2008 the quality parameters are not taken into account with the calculation of eligible income. Within this period, analyses of the impact of parameters on eligible income will be carried out.

\subsection{Price-cap method}

Price-cap regulation method is carried out with the assumption that sufficient income is ensured to cover eligible costs to perform the activity of a system operator.

The tolerance limit for price increase is expressed in relation to the eligible income. The capping is determined on the basis of the equation for $C P I-X$ and is given in the inequation below:

$$
(1+C P I-X) \cdot(1+Q) \geq \frac{\sum_{i=1}^{n} \sum_{j=1}^{m} p_{i j}^{t+1} \cdot q_{i j}^{N}}{\sum_{i=1}^{n} \sum_{j=1}^{m} p_{i j}^{t} \cdot q_{i j}^{O}}
$$

where for carrying out regulatory activities there are $n$ tariff categories, out of which each one has up to $m$ elements:

$p_{i j}^{t} \quad$ price in the form of tariff prices, charged in year $t$ for element $j$ of the tariff $i$;

$p_{i j}^{t+1} \quad$ price in the form of tariff prices, charged in year $t+1$ for element $j$ of the tariff $i$;

$q_{i j}^{N}$ in $q_{i j}^{O} \quad$ forecast or actual quantities of element

$j$ of the tariff $i$, which will be used ( $N$ expresses that the quantities refer to year $t+1$ and $O$ that the quantities refer to year $t$ );

$C P I \quad$ annual coefficient of consumer price changes;

$X \quad$ coefficient determined by the agency, reflects the demanded improvement of efficiency ( $U$ factor), while in addition, $X$ ensures income leveling in the regulatory period;

$Q \quad$ coefficient of supply reliability (continuity).

\subsection{Commercial quality}

The working subgroup for commercial quality has suggested monitoring parameters of commercial quality shown in table 3.1 .

The working subgroup for commercial quality will research the need for including additional parameters of commercial quality into the $»$ Rules of commercial quality level«, where it will take into consideration the acquired experience of monitoring commercial quality in Slovenia and the recommendations of CEER. 
Table 3.1 - A proposal for monitoring commercial quality

\begin{tabular}{|c|c|c|c|c|}
\hline \multicolumn{2}{|c|}{ Commercial quality } & Agency proposal & Legislation & CEER \\
\hline \multirow[b]{4}{*}{ 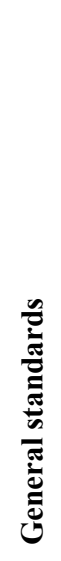 } & $\begin{array}{l}\text { Time of reestablishing electricity } \\
\text { supply in cases of accidental } \\
\text { (unplanned) interruptions }\end{array}$ & $\begin{array}{l}85 \% \text { of consumers in } \\
3 \text { hours; } 100 \% \text { in } 24 \\
\text { hours }\end{array}$ & & \\
\hline & $\begin{array}{l}\text { Time of minor work implementation } \\
\text { (meter change, manufacture of a } \\
\text { new low-voltage connection) }\end{array}$ & $\begin{array}{l}\text { In } 20 \text { working days } \\
95 \% \text { of work carried } \\
\text { out }\end{array}$ & & $*$ \\
\hline & $\begin{array}{l}\text { Time needed to connect a consumer } \\
\text { to a system }\end{array}$ & & & \\
\hline & $\begin{array}{l}\text { Time for replying to consumer's } \\
\text { questions (not just a courteous } \\
\text { reply) }\end{array}$ & $\begin{array}{l}90 \% \text { in } 10 \text { working } \\
\text { days }\end{array}$ & $\begin{array}{l}16 \text { days }(8+8) \\
\text { (Article } 5 \text { of the } \\
\text { Official Gazette } \\
117 / 2002)\end{array}$ & $\begin{array}{l}15 \text { days } \\
\text { (exceptionally a longer } \\
\text { time limit, prescribed in } \\
\text { the notification to the } \\
\text { consumer, including the } \\
\text { reasons) }\end{array}$ \\
\hline \multirow{7}{*}{ 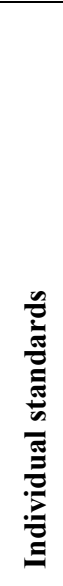 } & $\begin{array}{l}\text { Time for reconnection after debt } \\
\text { payment }\end{array}$ & in 1 working day & $\begin{array}{l}\text { in } 24 \text { hours } \\
\text { (Article } 78 \text { of the } \\
\text { Official Gazette } \\
\text { 26/2005, EZ-UPB1) }\end{array}$ & in 1 working day \\
\hline & Time for responding to a blown fuse & 6 hours & $\begin{array}{l}\text { In } 24 \text { hours } \\
\text { (Article } 78 \text { of the } \\
\text { Official Gazette } \\
\text { 26/2005, EZ-UPB1) }\end{array}$ & 3-4 hours \\
\hline & Time of announced visitation & Within 3 hours & - & Within 4 hours \\
\hline & $\begin{array}{l}\text { Time of drawing up pro forma } \\
\text { invoice }\end{array}$ & in 10 working days & - & * \\
\hline & $\begin{array}{l}\text { Time of handling a claim regarding } \\
\text { meters }\end{array}$ & in 10 working days & - & In 15 days \\
\hline & $\begin{array}{l}\text { Time of handling a claim regarding } \\
\text { costs or payment }\end{array}$ & in 10 working days & - & In 15 days \\
\hline & Time needed to activate connection & in 8 working days & - & in 2-5 working days \\
\hline
\end{tabular}

* - Coordination of the definition and classification of the activity of »minor« and »complex« work on the level of CEER is under way

\subsection{Reliability (continuity)}

In accordance with the legal bases, system indices SAIDI and SAIFI will be used to monitor reliability of supplying consumers in cases of individual system operators.

\subsection{Voltage quality}

For the needs of quality monitoring, distribution system operators carry out measurements of the following parameters:

- power frequency,

- magnitude of the supply voltage

- supply voltage variations,

- short and long interruptions of the supply voltage,

- rapid voltage changes, overvoltages and voltage dips,

- harmonic and interharmonic voltages,

- flicker,

- supply voltage unbalance,

- mains signaling on the supply voltage,

\section{Disturbance transiting among voltage levels}

When electricity supply is reliable enough, we need to ensure to the consumers power quality also in those parameters which are seemingly invisible. By that we mean especially voltage form (voltage dips, rapid changes and harmonics). Such disturbance can appear on the voltage level of consumers or it can be a consequence of lightning or switching surges on higher voltage levels. With the remuneration (incentive/penalty regime) of quality supply manager it is essential to pinpoint the place of disturbance.

\subsection{Harmonics}

The energy transformer represents higher impedance to higher harmonic components than to the basic frequency. When measuring higher harmonics we have come across a pattern from an aluminium factory basically in the entire Slovenian $110 \mathrm{kV}$ system whereas geographically it was not close - right behind the transformer. 


\subsection{Rapid voltage changes}

Voltage fluctuation "runs" through a transformer in a practically unimpeded manner. The fluctuation frequency is much lower that the industry frequency.

\subsection{Transient overvoltages}

Transient overvoltage is normally a consequence of lightning discharges, switching or fuse operation. Rise time of transient overvoltage can be shorter than a microsecond or it can last up to several milliseconds. Transient overvoltage is "smoothed" when passing from a higher voltage level to a lower one and it reduces proportionally.

\subsection{Supply interruptions}

Generator starting is set in such a manner that the system operating voltage with regard to voltage drops due to load current is on the reactance of the generator, transformers and lines. In case of sudden load shedding, after quick oscillation of the starting (subtransient) phenomena in the system, the voltage is equal to the transient voltage of the generator until the latter is appropriately decreased by means of regulation in the exciting current.

\subsection{Load disconnecting}

In case of load disconnecting at the end of a long line, the voltage there increases (the Ferranti effect). This presents no problem in cases of short lines (in case of a $135 \mathrm{~km}$ long line the voltage increases by $1 \%$ ). In cases of longer lines it may occur that the capacity is prevalent to inductivity. In such cases we need to have inductivity present at the end of the line and reactive energy will be absorbed. The conditions can be represented by means of telegraph equations.

\section{Model}

In the past, research of transiting disturbance from one part of energy system to another was carried out by means of different instruments and methods, from computer to experimental. Transient system analyzers provided good matches with field measurements, still their usage in the increasingly extensive systems has become useless (unfeasible or inaccurate). "Live" research is nowadays practically unfeasible on a mid-voltage or high voltage level.

The development of big digital computers has brought about new possibilities in this area. Thirty years ago, a wide number of methods came to light along with their specificity for digital solutions of transient phenomena in an electricity system. Current PCs are capable enough and programs can be obtained in a user-friendly form. The majority of programs (Pscad, Matlab) are based on the EMTP program (Electro Magnetic Transient Program), developed by H. W. Dommel.

Matlab with its Powersys module has been selected as the software for modelling the electricity system of Slovenia due to its user-friendliness and possibility of fixed calculations. Since the dynamic model of the entire electricity system of Slovenia surpasses the capacities of available software and hardware, we were forced to use simplified models of individual elements.

A model of connected 400, 220 and $110 \mathrm{kV}$ systems with belonging transformers was constructed as a basis. Due to the limitations of software and hardware, only the part of the distribution system where impact is currently being observed is modelled in detail. All the remaining parts of the distribution systems are presented as constant loads, tied to the transmission system. Since detailed models of distribution systems can be prepared in advance, it is possible to connect them easily and quickly to the model of the transmission system. Thus it is possible to establish in a short time the impact of individual events in high-voltage systems on electricity quality in the selected points of the distribution systems, also on the $0,4 \mathrm{kV}$ level, if necessary.

The combined model of electricity system in Slovenia enables many studies of dynamic and static impact on occurrences in the systems, caused by elements and objects which are currently not connected to the system.

\section{Conclusion}

The aforementioned dynamic model was applied to analyze the impact of different events in the Slovene power system on power quality in the $0.4 \mathrm{kV}$ distribution network during transients and in steady states. The power quality in distribution network was analyzed on $0.4 \mathrm{kV}$ busbars in five substations (Cerkno, Škofja Loka, Vevče, Šentjur, Rače) for the following set of events: a switch-off of a $300 \mathrm{MVA}(400 \mathrm{kV} / 110 \mathrm{kV})$ power transformer in the substation Okroglo; a three-phase short circuit on $110 \mathrm{kV}$ busbars in the substation Kleče; a three-phase short circuit on $20 \mathrm{kV}$ busbars in the substation Rogaška Slatina and a switch-on in a pumping regime of pump-turbine plants Avče and Kozjak which are currently at the design stage.[L 17]

The results obtained show that aforementioned events in some points of Slovene transmission and distribution network can cause power quality distortion over that allowed by the power quality standards.

In order to carry out economic regulation of network charge, the Energy Agency of the Republic of Slovenia (Slovenian regulator) 
monitors quality of electricity supply, which is divided into: reliability (continuity) of supply, voltage quality and commercial quality. The Agency monitors the parameters of quality electricity supply with the intention of permanently increasing and maintaining its level, respectively. As a regulator it is also the arbitrator in cases of disputes among the system managers. The verdict is based on a thorough analysis of past events, performed only by means of a (computer) model.

\section{References}

1. H. W. Dommel: Digital Computer Solution of Electromagnetic Transients In Single - And Multiphase Networks. IEEE Transactions (PAS), Vol. 88, No.4, April 1969, pp. 388...98.

2. H. Dommel: »Berechnung Elektromagnetischer Ausgleichsvorgänge in Elektrischen Netzen mit Digitalrechnern«, Bulletin SEV, 60 Jg. (1969), No.12, S. 538...48.

3. W. Frey, P. Althammer: Die Berechnung Elektromagnetischer Ausgleichsvorgänge auf Leitungen mit Hilfe eines Digitalrechners. BBC Mitteilungen, 48 Jg. (1961), Nr. 5/6, S. 344-55.

4. H. Prinz, W. Zaengle, O.Völcker: Das Bergeron Verfahren zur Lösung von Wanderwellenaufgaben. Bulletin SEV, 53 Jg. (1962), Nr. 16, S. 725...39.

5. P. Althammer: Die Digitale Berechnung von Ausgleichsvorgängen In Elektrischen Netzwerkwn Unter Besonderer Berücksichtigung Komplizierter Randschaltungen. Bulletin SEV, 54 Jg. (1963), Nr. 19, S. 789...95.

6. P. Althammer: »Ein Beitrag zur Berechnung von Ausgleichsvorgängen auf Mehrleitersystemen«. Archiv für Elektrotechnik, 49 Band (1964), Heft 3, S. $170 \ldots 82$.

7. J. K. Snelson: Propagation of Travelling Waves on Transmission Lines - Frequency Dependent Parameters «, IEEE, Transactions (PAS), Vol. 91 (1972), No. 1.Jan. 1972, pp. 85 ... 91.

8. F. Kranjc, T. Zorič, D. Đonlagič, J. Voršič: Metode digitalnega izračuna notranjih prenapetosti $v$ visokonapetostnih elektroenergetskih sistemih, Raziskovalni projekt "Kvaliteta električne energije", Univerza v Ljubljani, Fakulteta za elektrotehniko, Ljubljana 1974

9. R. Lamedica, G. Esposito, E. Tironi, D. Zninelli, A. Prudenzi: A Survey on Power Quality Cost in Industrial Customers«, IEEE 2001

10. E. Pehani, B. Orel: Današnja kvaliteta električne energije v Sloveniji«, Inštitut za elektriško gospodarstvo, Ljubljana 1967

11. F. Kranjc, S. Leskovar, S. Štruc, j. Kern, J. Voršič: Osnovni elektriški parametri trifaznih prostih vodov, QEE (Kvaliteta električne energije), Fakulteta za elektrotehniko, Ljubljana 1973
12. A. Orgulan, D. Koritnik, L. Mikola, M. Stegne, J. Voršič: Primerjalna študija o kakovosti električne energije na ravni Evropske unije«, Študija za Agencijo za energijo Republike Slovenije, Univerza v Mariboru, Fakulteta za elektrotehniko, računalništvo in informatiko, Maribor 2002

13. EN 50160: »Voltage Characteristics of Electricity Supplied by Public Distribution Systems. «

14. IEEE 1564: Voltage Sag Indices

15. M. Tesarova, P. Hejtmankova, E. Dvorsky: Voltage Sag Site Indices, Power Engineering Conference, UM-FERI, Maribor, Slovenia, 2003.

16. N. Watson, J. Arrillaga, Power System Electromagnetic Simulation, IEE, 2003

17. K. Deželak, A. Korak, T. Konjic, G. Štumberger, J. Voršič, The Impact of Events in the Slovene High Voltage Network on the Power Quality in the Distribution Networks«. V: Transient phenomena in large electric power systems. Paris: CIGRÉ, 2007, 


\begin{tabular}{|c|c|c|}
\hline \multicolumn{3}{|c|}{ Ervin Seršen, univ. dipl. inž. el. } \\
\hline & Službeni naslov: & $\begin{array}{l}\text { Javna agencija Republike Slovenije za } \\
\text { energijo, } \\
\text { Strossmayerjeva ulica 30, } \\
2000 \text { Maribor, Slovenija } \\
\end{array}$ \\
\hline & Telefon: & $+386(0) 22340300$ \\
\hline & Fax: & $+386(0) 22340320$ \\
\hline & Elektronska pošta: & ervin.sersen@agen-rs.si \\
\hline
\end{tabular}

Ervin Seršen was born in Celje, Slovenia, on January the $1 \mathrm{~s}^{\mathrm{st}}, 1944$. He received his B.S. degree from the University of Ljubljana in 1968. From June 1968 to December 1979 he was Assistant engineer, consultant engineer, head of research and development for household refrigerators and freezers at Gorenje, Household Appliances, Velenje, Slovenia. From January 1980 to March 1981, he was head of development department at Elektrosignal, Celje, Slovenia: Design and erection of electrical and lightning protection installations. From March 1981 to June 1994, he was senior test engineer, consultant engineer at Gorenje, Research and Development, Velenje, Slovenia. From June 1994 to February 2001, mr. Seršen was counsellor to the director, general secretary of the Slovenian Electro technical Committee, at Standards and Metrology Institute (Slovenian Institute for Standardization), Ljubljana, Slovenia. March 2001 to present, he is senior technical expert at Regulatory authority for electricity and gas; Issuing Renewable Energy Certificates (RECS), grid connections for renewable and CHP energy sources, quality of supply, standardization and related issues.

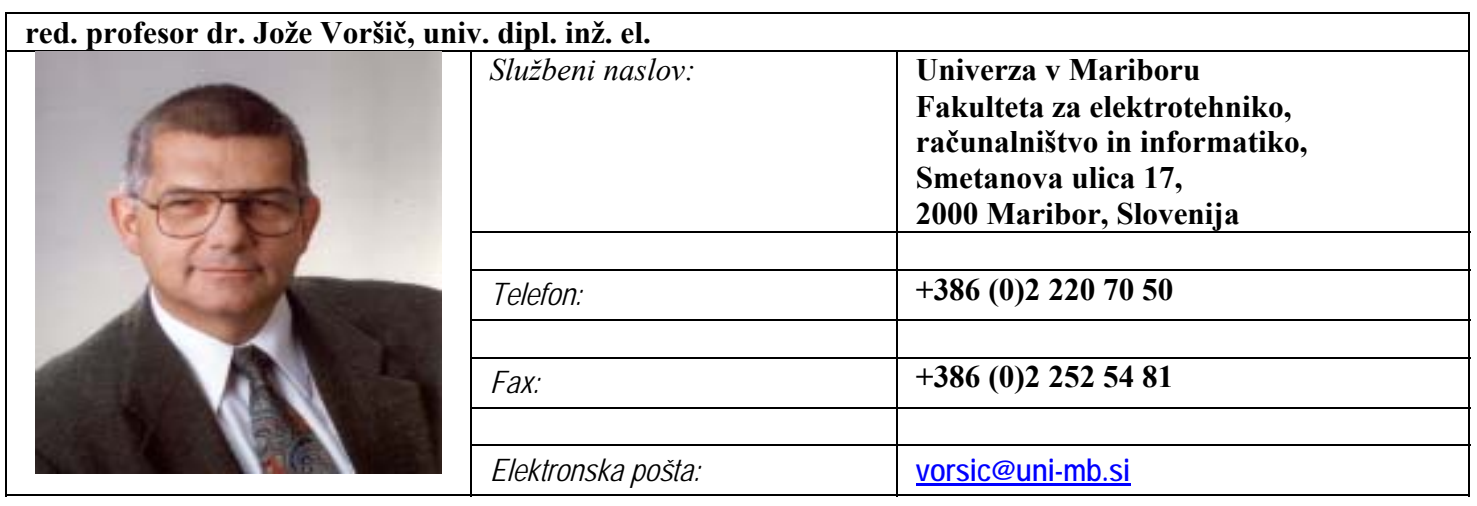

Jože Voršič was born in Maribor, Slovenia, on November 24, 1946. He received his B.S. degree from the University of Ljubljana in 1972, his M.S. degree from the University of Zagreb in 1982, and his Ph.D. degree from the University of Maribor in 1983, all in electrical engineering. In 1972 he was engaged at the University of Ljubljana as a research assistant. His work was focused on the research of the quality of electrical energy. In 1974 he joined the University of Maribor as an assistant. At present, he is Professor of Power Systems Engineering. From 1976 he was an active member of the self managerial governing bodies of the Faculty of Technical Sciences, and later at the Educational Community of R Slovenia and the Ministry of Science and Technology. He is a member of IEEE (The Institute of Electrical and Electronic Engineers), CIGRE (Conference Internationale des Grands Réseaux Electriques), WEC (World Energy Council), ED Maribor (elektrotehniško društvo) and SDVD (Slovensko društvo za visokošolsko didaktiko). 